\title{
受傷原因からみた罆椎外傷の検討
}

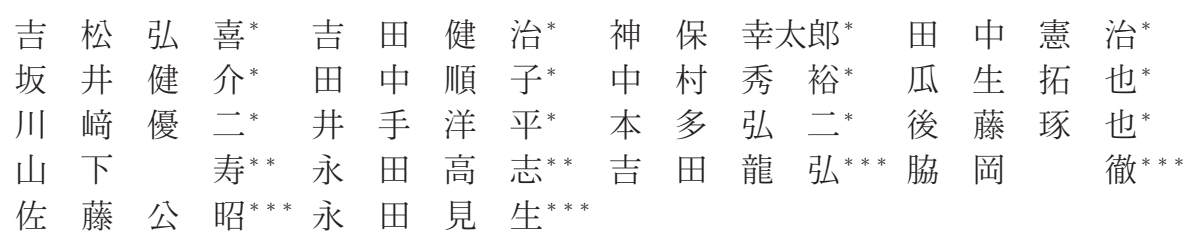

\section{A Study of the Cervical Spine in Patients with Blunt Trauma according to Cause of Injury}

\author{
Hiroki Yoshimatsu*, Kenji Yoshida*, Kotaro Jimbo*, Kenji Tanaka*, \\ Kensuke Sakai*, Junko Tanaka*, Hidehiro Nakamura*, Takuya Uryu*, \\ Yuji Kawasaki*, Yohei Ide*, Koji Honda*, Takuya Goto*, \\ Hisashi Yamashita**, Takashi Nagata**, Tatsuhiro Yoshida***, \\ Toru Wakioka***, Kimiaki Sato***, and Kensei Nagata***
}

救急外来での頚椎外傷患者の診察には，見逃しやすい頚椎・頚䯣損傷への深い認識が必要とされる．今 回，当院救急外来を受診した䅡椎外傷 6923 例について受傷原因別に調査した。頚椎外傷の受傷原因は交 通外傷 5325 例, 転落 490 例, 転落 318 例であった。交通外傷の内訳は四輪車対四輪車が 3401 例, 二輪車 対四輪車が 472 例, 四輪車単独が 454 名であった。頚椎・頚䯣損傷を 136 例 $(2.0 \%)$ 亿認めた。頚椎・頚 䯣損傷の受傷原因として転倒，転落，四輪車対四輪車事故の頻度が高く，自転車単独事故，転倒，墜落， 転落では頚椎・頚䯣損傷の割合が高かった。特に，自転車単独事故群では頚椎・頚䯣損傷の割合が高く， 危険察知対応能力の低下などの関与が考えられた。

In the clinical examination of emergency outpatients with cervical spine trauma, it is necessary to have a deep understanding of cervical spine injury. In this study, we investigated 6923 cases of cervical spine with blunt trauma who visited our emergency room according to the cause of injury. The causes of cervical spine injury included traffic injuries in 5325 cases, fall from $<1 \mathrm{~m}$ in 490 cases, and fall $\geqq 1 \mathrm{~m}$ in 318 cases. The breakdown of traffic injuries included 3401 cases due to accidents between four-wheeled vehicles, 472 cases due to accidents between a two-wheeled vehicle and a fourwheeled vehicle, and 454 cases due to accidents involving a single four-wheeled vehicle. Cervical spine injury, spinal cord injury, or both were observed in 136 cases. Among the causes, falls and accidents between four-wheeled vehicles were observed at a high frequency, and the rate was high in accidents involving a single bicycle and cases who suffered falls. The rates were particularly high in the group associated with accidents involving a single bicycle, and it was therefore believed that a reduced ability to sense and respond to danger was involved.

Key words : blunt trauma（鈍的外傷), cervical spine (䅡椎), cause of injury（受傷原因）

目的

救急外来での頝椎外傷の診断には見逃しやすい䅡椎・
頝䯣損傷例へのより深い認識が必要である。今回, 当 院救急外来を受診した頚椎外傷例を調查し，受傷原因 別に検討した。

* 聖マリア病院整形外科 Department of Orthopaedic Surgery, St. Mary's Hospital, Fukuoka, Japan

** 聖マリア病院救急科 Department of Emergency Medicine, St. Mary's Hospital, Fukuoka, Japan

*** 久留米大学整形外科 Department of Orthopaedic Surgery, Kurume University, School of Medicine, Fukuoka, Japan 
表 1 受傷原因別

\begin{tabular}{|c|c|c|c|c|c|}
\hline \hline & 交通外傷 & 転倒 & 転落 & スポーツ外傷 & 墜落 \\
\hline 総数 $(人)$ & 5325 & 490 & 318 & 229 & 194 \\
\hline 平均年齢 (歳) & 37 & 60 & 50 & 25 & 46 \\
\hline 救急車搬入 (人) & $2734(51 \%)$ & $379(77 \%)$ & $241(76 \%)$ & $105(46 \%)$ & $164(85 \%)$ \\
\hline 意識障害 & $367(7 \%)$ & $136(28 \%)$ & $64(20 \%)$ & $12(5 \%)$ & $39(20 \%)$ \\
\hline 飲酒 & $98(2 \%)$ & $109(22 \%)$ & $50(16 \%)$ & 0 & $9(5 \%)$ \\
\hline 頭部外傷 & $2470(46 \%)$ & $436(89 \%)$ & $275(86 \%)$ & $133(58 \%)$ & $161(83 \%)$ \\
\hline 顔面部外傷 & $829(16 \%)$ & $157(32 \%)$ & $98(31 \%)$ & $24(10 \%)$ & $60(31 \%)$ \\
\hline 頝椎・頚䯣損傷 & $55(1 \%)$ & $42(9 \%)$ & $19(6 \%)$ & $3(1 \%)$ & $13(7 \%)$ \\
\hline
\end{tabular}

\section{対}

平成 17 年から 3 年半の間に当院救急外来を受診し た頝椎外傷患者 6923 例について検討した。さらに， 受傷原因別に調査した.

当院は救命救急センターを有する地域中核病院であ る. 救急患者の 1 日来院数は平均 170 人， その内救急 車搬送台数は平均 27 台である。年間救急車搬送総数 は約 1 万台で，救急患者総数は約 6 万人である．軽症 から重症までの救急患者全てを引き受けており, 年々 救急患者，救急車搬送台数共に増加している.

\section{結果}

男性 3858 例, 女性 3065 例で, 平均年齢は 39 歳で あった。救急車搬入は 3796 例 (55\%) で，紹介は 331 例 $(5 \%)$ であった。高エネルギー外傷は 523 例（8 $\%$ ，意識障害は 684 例 $(10 \%)$, 飲酒は 295 例（ $4 \%$ ) であった，頭部外傷を 3710 例（54\%）に，顔面部外 傷を 1295 例（19\%）に認めた。受傷原因は交通外傷 5325 例 (77\%), 転倒 490 例, 転落 318 例，スポーツ 外傷 229 例，墜落 194 例であった。交通外傷 5325 例 中では四輪車対四輪車が 3401 例 $(64 \%)$ ，二輪車対四 輪車 472 例, 四輪車単独 454 例, 自転車対四輪車 415 例, 歩行者対四輪車 241 例, 自転車単独 117 例, 二輪 車単独 114 例であった。

頚椎損傷・頚䯣損傷を 136 例（2.0\%）に認めた. 頚椎損傷単独 53 例, 頚䯣損傷単独 53 例, 頚椎損傷頚 骾損傷合併 30 例であった。この 136 例では救急車搬 入 128 例 $(94 \%)$ ，紹介 49 例 $(36 \%)$ ，高エネルギー 外傷 29 例 (21\%)，意識障害 50 例 $(37 \%)$ ，飲酒 24 例 (18\%)，頭部外傷 115 例 (85\%)，顔面部外傷 46
例（34\%）であった。また，この受傷原因は交通外傷 55 例 (40\%)，転倒 42 例，転落 19 例，墜落 13 例で あった．交通外傷 55 例中では四輪車対四輪車 18 例 (33\%)，自転車単独 12 例，四輪車単独 7 例，歩行者 対四輪車 7 例，二輪車対四輪車 6 例であった.

受傷原因別に検討すると，表 1 の如くであった．交 通外傷 5325 例では頚椎・頝髄損傷が $1 \%$ であった。 転倒 490 例では, 平均年齢 60 歳, 意識障害 $28 \%$, 飲 酒 22\%，頚椎・頚䯣損傷 $9 \%$ であった。交通外傷を 仔細に検討すると，表 2 の如くであった。四輪車対四 輪車 3401 例では頚椎・頚髄損傷 $1 \%$ であり，二輪車 対四輪車 472 例では $1 \%$, 四輪車単独 454 例では $2 \%$ であった。自転車単独 117 例では，頚椎・頚髄損傷を 10\%に認め，意識障害 26\%，飲酒 15\%，頭部外傷 84 \%，顔面部外傷 43\%であった。

\section{考察}

救急外来での頝椎外傷は頚椎・頚䯣損傷を見逃さな いことが最も重要であり，より深い認識 ${ }^{3)}$ が必要とな る。受傷原因に関する過去の報告 ${ }^{4) 5)}$ では交通外傷, 転倒などが多いと報告され，若年者では交通外傷・ス ポーツ外傷などの強い外力の加わる場合に多く，高齢 者では転倒などの比較的軽微な外力による場合に多い とされている. BTLS では春髄・脊髄損傷を疑うべき 受傷機転として高速度の自動車事故, 身長の 3 倍以上 の高さからの墜落，軸方向への荷重，飛び込み事故な どを上げている。一方で頚椎外傷の受傷原因に関する 報告 ${ }^{2)}$ は少なく, カナダの報告 ${ }^{1)}$ では交通外傷が 75 \%を占めている.

今回の調査では，頚椎・頚髄損傷を 136 例 (2.0\%) に認めた，頚椎・頚髄損傷の受傷原因として転倒，転 
表 2 交通外傷内訳

\begin{tabular}{|c|c|c|c|c|c|c|c}
\hline \hline & 四輪車対四輪車 & 二輪車対四輪車 & 四輪車単独 & 自転車対四輪車歩行者対四輪車 & 自転車単独 & 二輪車単独 \\
\hline 総数 $(人)$ & 3401 & 472 & 454 & 415 & 241 & 117 & 114 \\
\hline 年齢 $($ 歳 & 37 & 32 & 35 & 40 & 42 & 41 & 33 \\
\hline 救急車搬入 $(人)$ & $1245(37 \%)$ & $367(78 \%)$ & $309(69 \%)$ & $341(82 \%)$ & $217(90 \%)$ & $92(78 \%)$ & $83(73 \%)$ \\
\hline 意識障害 & $91(3 \%)$ & $49(10 \%)$ & $43(9 \%)$ & $56(13 \%)$ & $63(26 \%)$ & $31(26 \%)$ & $18(16 \%)$ \\
\hline 飲酒 & $21(1 \%)$ & $6(1 \%)$ & $23(5 \%)$ & $6(1 \%)$ & $16(7 \%)$ & $17(15 \%)$ & $2(2 \%)$ \\
\hline 頭部外傷 & $1092(32 \%)$ & $318(67 \%)$ & $284(63 \%)$ & $328(79 \%)$ & $206(85 \%)$ & $98(84 \%)$ & $73(64 \%)$ \\
\hline 顔面部外傷 & $255(7 \%)$ & $121(26 \%)$ & $139(31 \%)$ & $108(26 \%)$ & $87(36 \%)$ & $50(43 \%)$ & $39(34 \%)$ \\
\hline 頚椎・頚䯣損傷 & $18(1 \%)$ & $6(1 \%)$ & $7(2 \%)$ & 2 & $7(3 \%)$ & $12(10 \%)$ & $1(1 \%)$ \\
\hline
\end{tabular}

落, 四輪車対四輪車事故の頻度が高く, 自転車単独事 故, 転倒, 墜落, 転落では頚椎・頚骾損傷の割合が高 かった。

特に, 自転車単独事故群では䅡椎・頚䯣損傷の割合 が高かったが，過去に仔細な報告はない，詳しく検討 すると, 頚椎外傷例では学生と中高年に多く, 頚椎・ 頚髄損傷例では高齢者と飲酒している中年層に多かっ た。受傷機序としては, 危険察知対応能力の低下, 頭 部・顔面部が衝突することにより顤部に集中的に外力 が加わった, 過伸展外力, 軸圧の関与などが考えられ た。また，転倒群では䅡椎外傷例，頚椎・頚䯣損傷例 共に高齢者が多く，春柱管狭窄の関与む指摘されてお り，高齢者の転倒には注意が必要と思われた。

\section{結語}

救急外来に打ける頚椎外傷 6923 例中, 頚椎損傷 • 頝䯣損傷を 136 例（2.0\%）に認めた。自転車単独事
故，転倒，墜落，転落では頚椎・頚䯣損傷の割合が高 かった。

\section{参 考 文 献}

1) Ian, G. S., et al. : The Canadian C-Sine Rule versus the NEXUS Low-Risk Criteria in Patients with Trauma. N. Engl. J. Med., 349 : 2510-2518, 2003.

2) Jerome, R. H., et al. : Validity of a set of clinical criteria to rule out injury to the cervical spine in patients with blunt trauma. N. Engl. J. Med., 343 : 94-99, 2000.

3）永田見生：頚椎疾患の $X$ 線診断とその留意点. 日本脊 椎春䯣病学会雑誌， $18 ： 705-716,2007$.

4）新宮彦助：日本に打ける脊㖪損傷疫学調查第 3 報. 日本パラプレジア医学会雑誌， 8：26-27，1995。

5）山田裕彦弓：頚椎・頚髄損傷症例の臨床的検討。日外 傷会誌，12：274-280，1998. 